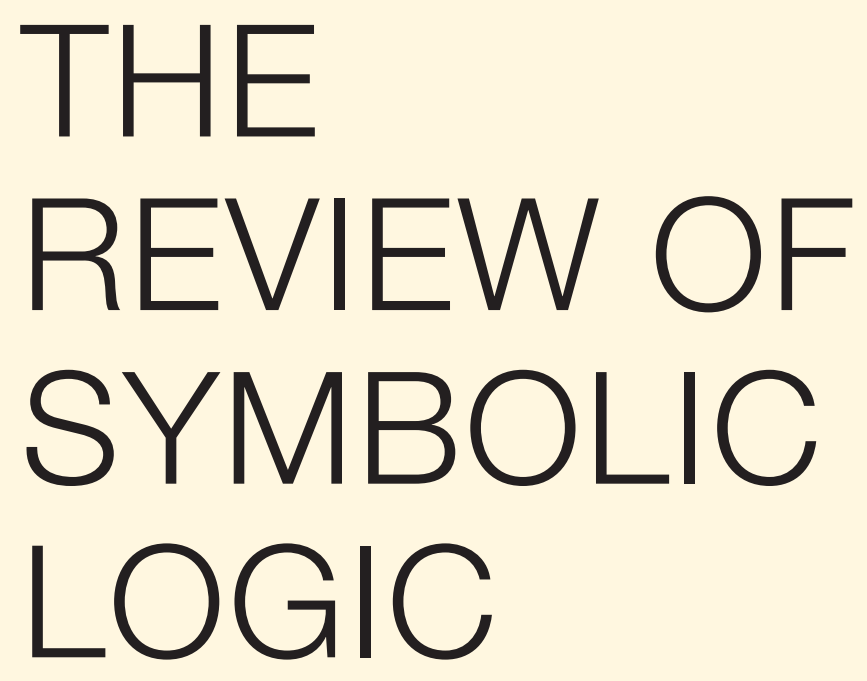

\title{
Edited by
}

Jeremy Avigad, Coordinating Editor

Rosalie lemhoff

Hannes Leitgeb

Carsten Lutz

Paolo Mancosu

Graham Priest

lan Proops

Alasdair Urquhart

Richard Zach

VOLUME 4 • NUMBER 1 • MARCH 2011 • ISSN 1755-0203

Copyright (c) 2011 by the Association for Symbolic Logic. All rights reserved.

Reproduction by photostat, photo-print, microfilm, or like process by permission only. 


\title{
THE REVIEW OF SYMBOLIC LOGIC
}

\author{
Coordinating Editor \\ Jeremy Avigad \\ Departments of Philosophy and Mathematical Sciences \\ Carnegie Mellon University
}

\section{Editors}

Rosalie Iemhoff

Department of Philosophy

Utrecht University

Hannes Leitgeb

Faculty of Philosophy, Philosophy of

Science, and Study of Religion

Ludwig-Maximilians-University, Munich

Carsten Lutz

Department of Computer Science

University of Bremen

Paolo Mancosu

Department of Philosophy

University of California, Berkeley
Graham Priest

The Graduate Center

City University of New York

Ian Proops

Department of Philosophy

University of Michigan

Alasdair Urquhart

Departments of Philosophy and

Computer Science

University of Toronto

Richard Zach

Department of Philosophy

University of Calgary

\section{Advisory Board}

Steve Awodey

Department of Philosophy

Carnegie Mellon University

Hartry Field

Department of Philosophy

New York University

Kit Fine

Departments of Philosophy

and Mathematics

New York University

Michael Friedman

Department of Philosophy

Stanford University

Marcus Kracht

Department of Linguistic and

Literary Studies

University of Bielefeld

John MacFarlane

Department of Philosophy and

Group in Logic and

Methodology of Science

University of California, Berkeley

Ruth Barcan Marcus

Department of Philosophy

Yale University

D.A. Martin

Departments of Mathematics

and Philosophy

University of California,

Los Angeles

Lawrence Moss

Department of Mathematics

Indiana University
Ulrike Sattler

School of Computer Science

University of Manchester

Colin Stirling

School of Informatics

University of Edinburgh

James Tappenden

Department of Philosophy

University of Michigan

Johan van Benthem

Institute for Logic,

Language

and Computation

University of Amsterdam and

Department of Philosophy

Stanford University

Michiel van Lambalgen

Institute for Logic,

Language and

Computation and

Department of Philosophy

University of Amsterdam

Dag Westerståhl

Department of Philosophy

Gothenburg University

Mark Wilson

Department of Philosophy

Pittsburgh University

Crispin Wright

Department of Philosophy

University of St. Andrews and

New York University 


\section{TABLE OF CONTENTS}

Canonicity Results of Substructural and Lattice-Based Logics

TOMOYUKI SUZUKI . . . . . . . . . . . . . . . . . 1

A Sequent Calculus Isomorphic to Gentzen's Natural Deduction

JAN VON PLATO . . . . . . . . . . . . . . . . . . . . . . 43

On the Infinite in Mereology with Plural Quantification

MASSIMILIANO CARRARA AND ENRICO MARTINO . . . . . . . . . 54

Expressible Semantics for Expressible Counterfactuals

EMMANUEL CHEMLA . . . . . . . . . . . . . . . . . . . 63

Positive Fragments of Relevance Logic and Algebras of Binary Relations ROBIN HIRSCH AND SZABOLCS MIKULÁS . . . . . . . . . . . 81

The Inadequacy of a Proposed Paraconsistent Set Theory

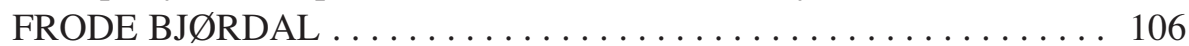

Reply to Bjørdal

ZACH WEBER . . . . . . . . . . . . . . . . . . . . . . . . 109

Hume's Principle, Beginnings

ALBERT VISSER . . . . . . . . . . . . . . . . . . . . . . . . 114

Degree Supervaluational Logic

J. ROBERT G. WILLIAMS . . . . . . . . . . . . . . . . . . . . . . . . . 130

Polynomial Ring Calculus for Modal Logics: A New Semantics and Proof Method for Modalities

JUAN C. AGUDELO AND WALTER CARNIELLI . . . . . . . . . . . 150 
Subscription Information: Review of Symbolic Logic (ISSN 1755-0203) is published quarterly by Cambridge University Press for the Association for Symbolic Logic. Annual subscription rates for Volume 4 (2011): Institutional subscription rates, print and online: US \$680.00 in the USA, Canada, and Mexico; UK $£ 415.00$ + VAT elsewhere. Institutional subscription rates, online only: US $\$ 572.00$ in the USA, Canada, and Mexico; UK $£ 368.00+$ VAT elsewhere. Institutional subscription rates, print only: US \$645.00 in the USA, Canada, and Mexico; UK $£ 385.00$ + VAT elsewhere. Individual subscription rates, online only: US $\$ 143.00$ in the USA, Canada, and Mexico; UK $£ 92.00$ + VAT elsewhere. Individual subscription rates, print only: US \$162.00 in the USA, Canada, and Mexico; UK £97.00 + VAT elsewhere. Institutional subscription correspondence should be sent to: Cambridge University Press, 100 Brook Hill Drive, West Nyack, NY 10994, USA, for customers in the USA, Canada, or Mexico. Customers elsewhere should contact: Cambridge University Press, The Edinburgh Building, Shaftesbury Road, Cambridge CB2 8RU, UK.

Association for Symbolic Logic. Individual Members of the Association for Symbolic Logic receive a print subscription to The Review of Symbolic Logic as a benefit of membership. Requests for information, applications for membership, orders for back volumes, business correspondence, and notices and announcements for publication in the The Bulletin of Symbolic Logic should be sent to the Secretary-Treasurer of the Association: Charles Steinhorn, ASL, Box 742, Vassar College, 124 Raymond Avenue, Poughkeepsie, NY 12604, USA. The email address of the Association's business office is asl@vassar.edu. The ASL website is located at http://www.aslonline.org. Links from that site provide further information on the Review and on submitting papers for publication.

Coordinating Editor: Jeremy Avigad, Department of Philosophy, Carnegie Mellon University, Pittsburgh, PA 15213, USA. Email: avigad@cmu.edu.

Copyright: All rights reserved. No part of this publication may be reproduced, in any form or by any means, electronic, photocopy, or otherwise, without permission in writing from Cambridge University Press. Photocopying information for users in the U.S.A.: Copying for internal or personal use beyond that permitted by Sec. 107 or 108 of the U.S. Copyright Law is authorized for users duly registered with the Copyright Clearance Center (CCC) Transaction Reporting Service, provided that the appropriate remittance per article is paid directly to CCC, 222 Rosewood Drive, Danvers, MA 01923, USA. Specific written permission must be obtained for all other copying. General enquiries from the USA, Mexico, and Canada should be addressed to the New York office of Cambridge University Press http://www.cambridge.org/us/information/rights/contacts/newyork.htm; general enquiries from elsewhere should be addressed to the Cambridge office http://www.cambridge.org/ uk/information/rights/contacts/cambridge.htm; permission enquiries from Australia and New Zealand should be addressed to the Melbourne office http://www.cambridge.org/aus/ information/contacts_melbourne.htm; enquiries regarding Spanish-language translation rights (only) should be addressed to the Madrid office http://www.cambridge.org/uk/ information/rights/contacts/madrid.htm

Copyright $(\subset$ Association for Symbolic Logic, 2011 